\title{
Development of fermented beverage using corn silk and mulberry leaf extracts
}

\author{
Se-Woong Oh, Jae-Hoon Hong* \\ Department of Pharmaceutics and Bio Technology, Konyang University, Daejeon 35365, Korea
}

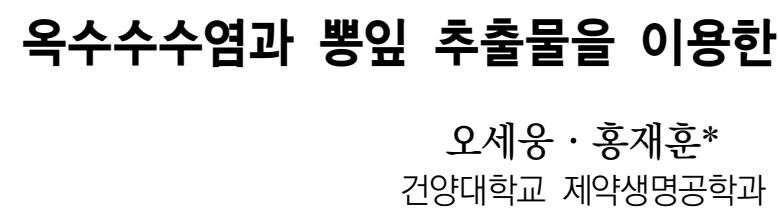

\begin{abstract}
The qualitative changes of the fermented beverage prepared from com silk (Zea mays L.) and mulberry leaf (Morus alba) extracts were investigated. The thickness of cellulose was 7.17-8.30 mm after 15 days of fermentation. Moreover, the pH significantly decreased to 3.68-3.93 (p<0.05) and the total acidity increased significantly to $3.41-3.77 \%(p<0.05)$, indicating Gluconacetobacter xylinus fermentation activity. The total flavonoid and phenol contents were 37.42-164.65 $\mu \mathrm{g} / \mathrm{mL}$ and 138.67-620.17 $\mu \mathrm{g} / \mathrm{mL}$, respectively. The DPPH and ABTS radical scavenging and reducing powers were 23.87-69.39\%, 59.92-75.68\% and 27.27-82.33\%, respectively. Com silk showed antimicrobial activity for all test strains, especially Acinetobacter calcoaceticus, Bacillus coagulans and Escherichia coli. In addition, although antidiabetic activity of the fermented beverage (22.51-33.66\%) was lower than that of acarbose control, the fermented beverage may prove to be a natural altemative. There was no observable synergy between the active ingredients in the beverage. Further, mulberry leaf had a significantly higher contribution to the total flavonoid and phenol contents, as well as the antioxidant, antidiabetic, and antimicrobial activities, compared to corn silk. The results of the study confirmed the functional characteristics of the novel fermented beverage. Further evaluation is needed for the analysis of sensory characteristics of the novel fermented beverage.
\end{abstract}

Key words : fermented beverage, corn silk, mulberry leaf, anti-oxidative activity, anti-microbial activity

\begin{abstract}
서 론
발효를 거친 음료는 미생물이 성장하며 ethanol을 생산하는 알코올형 음료와 유기산을 생산하는 산형 음료로 구분되어지며, 국가, 지역에 따라 다양한 형태로 제조되고 있다(Uzogara 등, 1990). Gluconacetobacter spp.는 Acetobacter spp., Azotobacter spp.와 같이 산형음료 제조에 이용되는 대표적인 초산균 중 하나로, 발효과정을 거치며 tea fungus라 불리는 유백색의
\end{abstract}

cellulose 막을 형성하고 acetic acid, malic acid, glucuronic aicd, usnic acid 등의 유기산을 생산하는 것으로 알려져 있다 (Bauer-Petrovska와 Petrushevska-Tozi, 2000; Sreeramulu 등, 2000). 그러나 발효음료는 오랜 기간 제조되어 마셔온 전통 음료이긴 하지만, 현대인의 변해가는 기호도에 따른 연구개 발은 미비한 실정으로 이에 다양한 연구가 필요한 실정이다.

옥수수수염은 화본과 1년생 초본인 옥수수의 부산물로서 황색, 담갈색을 띠며 inositol, cryptoxanthin, pantothenic

\footnotetext{
*Corresponding author. E-mail : jhhong@konyang.ac.kr, Phone : +82-42-600-8501, Fax : +82-42-600-8477

Received 19 January 2021; Revised 02 February 2021; Accepted 14 February 2021.

Copyright (c) The Korean Society of Food Preservation.

This is an Open Access article distributed under the terms of the Creative Commons Attribution Non-Commercial License (http://creativecommons.org/licenses/by-nc/4.0) which permits unrestricted non-commercial use, distribution, and reproduction in any medium, provided the original work is properly cited.
} 
acid, ascorbic acid, vitamin K, sitosterol, stigmasterol, malic acid, tartaric acid 등을 함유하고 있다(Kang과 Bae, 2015). 특히 2차 대사산물인 flavone glycoside 중 maysin의 함량이 높은 것으로 보고되었으며, 선행 연구 결과에 따르면 항고지 혈증, 이담 및 이뇨 작용에 효과가 있는 것으로 보고되었다 (Tran 등, 2018). 하지만 이러한 효능이 있음에도 불구하고, 감미, 풋내의 관능적 특성을 활용하여 다류, 향료 및 첨가물 로 활용되기만 하여 다양한 소재의 원료로서의 응용 가능성 에 대한 연구가 필요하다.

뽕잎은 예로부터 누에 먹이로서 양잠용으로 사용해 왔으 나, 최근에는 암, 당뇨, 고혈압 및 고지혈증 등과 같은 성인병 에 효능이 있다고 보고되어 고부가가치 식의약 소재로 활용되 고 있다. 선행 연구 결과에 따르면 flavone glycoside, steroids, triterpenes, amino acids 등의 무기성분을 함유하고 있으며, 특히 $\gamma$-aminobutyric acid, chlorogenic acid, rutin, quercetin 등을 함유하여 항암, 항고혈압, 항당뇨 및 항산화 활성이 있는 것으로 보고되었으며(Jo 등, 2016), 녹차에 비해서도 $\gamma$ aminobutyric acid은 10 배, rutin은 3.8 배 함유하고 있어 영양 적으로도 우수한 것으로 보고되었다(Campisi 등, 2019). 하 지만 뽕잎을 이용하여 절편, 증편, 강정 등을 개발하는 가공 연구는 활발히 진행되어져 왔으나, 음료류의 원료로서의 연 구는 차류를 제외하고는 미비한 실정이므로 다방면의 연구가 요구된다.

따라서 본 연구에서는 산화 스트레스 억제 및 항당뇨 등의 생리 활성이 있는 것으로 보고된 옥수수수염, 뽕잎의 배합에 따른 추출물에 Gluconacetobacter xylinus 균주 접종 후 산형 발효하여 제조된 음료에 대해 균주 발효 특성, 기능성분 및 항산화, 항당뇨, 항균 활성을 비교 분석함으로써 원료의 배합 에 따른 기능성분 등의 상승효과 유무 및 영양적, 기능적, 기 호적 특성을 확보한 발효음료를 개발하고자 하였다.

\section{재료 및 방법}

\section{실험재료}

옥수수수염, 뽕잎의 배합에 따른 발효음료의 제조 원료는 2020년산 옥수수수염(Handsherb, Youngcheon, Korea), 뽕잎 (Handsherb), 정백당(CJ Cheiljedang, Seoul, Korea)을 사용 하였고, 발효를 위한 균주는 한국종균협회에서 G. xylinus subsp. xylinus(KCCM 41431)를 분양받아 사용하였다.

\section{발효음료 제조}

추출물은 옥수수수염, 뽕잎을 Table 1 과 같이 배합하여 고 압멸균기(AC-12, Dongbang hitech, Seoul, Korea)로 $90^{\circ} \mathrm{C}$ 에 서 60분 추출 후 여과지 No.1(Whatman, Midstone, UK)으로 여과한 것을 고압멸균기로 $65^{\circ} \mathrm{C}$ 에서 30 분 살균 후 상온에서 냉각시킨 것을 추출물로 사용하였으며, 옥수수수염, 뽕잎을 배합하여 제조한 추출물에 대해 G. medellinensis, G. oxydans 에 비해 유의적으로 높은 활성을 가졌던 G. xylinus 배양액을 $1 \%(\mathrm{v} / \mathrm{v})$ 를 접종하고 배양기(NB-201, N-biotech, Seoul, Korea) 에서 $25^{\circ} \mathrm{C}$ 로 15 일 발효 과정을 거쳐 옥수수수염, 뽕잎의 배 합에 따른 발효음료를 제조하였다.

\section{발효특성 분석}

G. xylinus는 발효과정을 거치며 표층에 cellulose 막을 형 성하는 것으로 보고되었다. Cellulose 두께 변화는 $300 \mathrm{~mL}$ 비커에 $200 \mathrm{~mL}$ 용량의 발효음료를 15 일간 3 일 주기로 digital caliper(BD500-100, Bluetech, Seoul, Korea)를 이용 하여 형성된 gel의 두께를 $\mathrm{mm}$ 로 나타냈다. $\mathrm{pH}$ 및 산도는 시 료를 원심분리기(FLETA-5, Hanil, Seoul, Korea)로 7,000 $\mathrm{rpm}$ 에서 15 분 원심 분리한 상징액을 시료로 사용하였으며, $\mathrm{pH}$ 는 $\mathrm{pH}$ meter(PH-201L, Mettler Toledo, Greifensee,

Table 1. Composition (\%) of fermented beverages using corn silk and mulberry leaf extracts

\begin{tabular}{|c|c|c|c|c|c|}
\hline \multirow{2}{*}{ Ingredients } & \multicolumn{5}{|c|}{ Samples ${ }^{1)}$} \\
\hline & $\mathrm{C} 2 \mathrm{M} 0$ & $\mathrm{C} 1.5 \mathrm{M} 0.5$ & C1M1 & $\mathrm{C} 1.5 \mathrm{M} 0.5$ & $\mathrm{C} 0 \mathrm{M} 2$ \\
\hline Water & 87 & 87 & 87 & 87 & 87 \\
\hline Corn silk & 2 & 1.5 & 1 & 0.5 & 0 \\
\hline Mulberry leaves & 0 & 0.5 & 1 & 1.5 & 2 \\
\hline Sugar & 10 & 10 & 10 & 10 & 10 \\
\hline Strain culture fluid & 1 & 1 & 1 & 1 & 1 \\
\hline
\end{tabular}

${ }^{1)} \mathrm{C} 2 \mathrm{M} 0$, corn silk $2 \%+$ mulberry leaves $0 \%$; $\mathrm{C} 1.5 \mathrm{M} 0.5$, corn silk $1.5 \%+$ mulberry leaves $0.5 \%$; $\mathrm{C} 1 \mathrm{M} 1$, corn silk $1 \%+$ mulberry leaves $1 \%$; $\mathrm{C} 0.5 \mathrm{M} 1.5$, corn silk $0.5 \%+$ mulberry leaves $1.5 \%$; $\mathrm{C} 0 \mathrm{M} 2$, corn silk $0 \%+$ mulberry leaves $2 \%$. 
Swiss)를 이용하여 측정하였고, 산도는 시료 $20 \mathrm{~mL}$ 를 취하 여 $1 \mathrm{~N} \mathrm{NaOH}$ (Samchun, Seoul, Korea)로 $\mathrm{pH}$ 8.4가 될 때까 지 적정하여 적정한 $\mathrm{mL}$ 를 acetic acid $\%(\mathrm{v} / \mathrm{v})$ 함량으로 환산 하여 나타냈다. 결과값은 3 회 반복 수행하여 도출한 평균값 을 제시하였다.

\section{총플라보노이드 함량 분석}

Moreno의 방법(Moreno 등, 2000)을 응용하여 분석하였으 며, 각각의 시료 $0.5 \mathrm{~mL}$ 에 $10 \%(\mathrm{w} / \mathrm{v})$ aluminium nitrate (Samchun), $1 \mathrm{M}$ potassium acetate(Samchun) 각 $0.1 \mathrm{~mL}$ 와 $80 \%(\mathrm{v} / \mathrm{v})$ ethanol(Duksan, Seoul, Korea) $4.3 \mathrm{~mL}$ 를 차례로 가하여 혼합 후 실온에서 40 분간 암소 반응 후 UVspectrophotometer(Optizen Pop, Klab, Tokyo, Japan)를 이용 하여 $415 \mathrm{~nm}$ 에서의 흡광도를 측정하였다. 표준물질로 quercetin (Sigma Chemical Co., St. Louis, MO, USA)을 사용하여 표 준검량선 작성하여 산출하였다. 결과값은 3 회 반복 수행하여 도출한 평균값을 제시하였다.

\section{총페놀 함량 분석}

Folin-Ciocalteu법(Rossi와 Singleton, 1965)을 응용하여 10\%(v/v) Folin-Ciocalteu reagent(Sigma Chemical Co.), $2 \%(\mathrm{w} / \mathrm{v})$ sodium carbonate(Samchun) 각 $1 \mathrm{~mL}$ 에 각각의 시 료 $1 \mathrm{~mL}$ 를 가하여 혼합하고 실온에서 60 분 암소 반응 후 $750 \mathrm{~nm}$ 에서의 흡광도를 3 회 반복 측정하였다. 표준물질로 ascorbic acid(Sigma Chemical Co.)를 사용하여 표준검량선 을 작성하여 산출하였다. 결과값은 3 회 반복 수행하여 도출 한 평균값을 제시하였다.

\section{$\mathrm{DPPH}$ 라디칼 소거능 측정}

Blois 방법(Blois, 1958)을 응용하여 $0.2 \mathrm{mM} \mathrm{DPPH}$ (Sigma Chemical Co.) $2 \mathrm{~mL}$ 에 각각의 시료 $1 \mathrm{~mL}$ 를 가하여 혼합하고, 실온에서 10 분간 암소 반응 후 $517 \mathrm{~nm}$ 에서의 흡 광도를 측정하여 나타내었다. 결과값은 3 회 반복 수행하여 도출한 평균값을 제시하였으며, 계산식은 다음과 같다.

Radical scavenging activity $(\%)=$

$$
\frac{\left(\mathrm{Abs}_{\text {blank }}-\mathrm{Abs}_{\text {sample }}\right)}{\mathrm{Abs}_{\text {blank }}} \times 100
$$

\section{$\mathrm{ABTS}$ 라디칼 소거능 측정}

$\operatorname{Re}$ 등의 방법( $\operatorname{Re}$ 등, 1999)을 응용하여 $7 \mathrm{mM} \mathrm{ABTS}$ (Sigma Chemical Co.) $50 \mathrm{~mL}$ 에 potassium persulfate(Duksan) 를 $2.4 \mathrm{mM}$ 이 되도록 용해시켜 실온에서 24시간 암소 반응 후 $415 \mathrm{~nm}$ 에서 흡광도가 1.5 이상이 되도록 증류수로 희석
하여 제조한 $\mathrm{ABTS}$ 용액 $3 \mathrm{~mL}$ 에 각각의 시료 $0.5 \mathrm{~mL}$ 를 가하 여 혼합하고, 실온에서 10 분간 암소 반응 후 $415 \mathrm{~nm}$ 에서의 흡광도를 측정하여 대조군인 ascorbic acid와 비교하였다. 결 과값은 3회 반복 수행하여 도출한 평균값을 제시하였으며, $\mathrm{DPPH}$ 라디칼 소거능과 동일한 계산식으로 산출하여 제시하 였다.

\section{환원력 측정}

Oyaizu의 방법(Oyaizu, 1986)을 응용하여 $200 \mathrm{mM}$ sodium phosphate(Samchun) buffer $(\mathrm{pH}$ 6.6)와 $1 \%(\mathrm{w} / \mathrm{v})$ potassium ferricyanide(Duksan) $1 \mathrm{~mL}$ 에 각각의 시료 $1 \mathrm{~mL}$ 를 가하여 혼합 후 항온수조(WB-6, WiseBath, Seoul, Korea) $50^{\circ} \mathrm{C}$ 에서 20 분 반응시키고, $10 \%(\mathrm{w} / \mathrm{v})$ trichloroacetic acid(Sigma Chemical Co.) $1 \mathrm{~mL}$ 를 가하여 반응을 정지시킨 후, 2,000 $\mathrm{rpm}$ 에서 15 분간 원심 분리하여 얻은 상징액 $2 \mathrm{~mL}$ 에 증류수 $2 \mathrm{~mL}$ 와 $0.1 \%(\mathrm{w} / \mathrm{v})$ iron chloride(Duksan) $1.6 \mathrm{~mL}$ 를 가한 후 $700 \mathrm{~nm}$ 에서의 흡광도를 측정하여 대조군인 ascorbic acid와 비교하였다. 결과값은 3 회 반복 수행하여 도출한 평균값을 제시하였으며, DPPH 라디칼 소거능과 동일한 계산식으로 산출하여 제시하였다.

\section{$\alpha$-Glucosidase 저해 활성 측정}

$\alpha$-Glucosidase 저해 활성은 $\mathrm{Sa}$ 등의 방법(Ji 등, 2017)을 응용하여 각각의 시료 $0.4 \mathrm{~mL}$ 에 $0.1 \mathrm{M}$ phosphate buffer (Samchun)(pH 6.9)에 $\alpha$-glucosidase(Sigma Chemical Co.)의 농도가 $0.2 \mathrm{U} / \mathrm{mL}$ 가 되도록 만들어 $0.8 \mathrm{~mL}$ 를 가한 후 incubator에서 $37^{\circ} \mathrm{C}$ 에서 10 분 배양 후 $1.5 \mathrm{mM}$ p-nitrophenyl$\alpha$-D-gluco-pyranoside solution(Sigma Chemical Co.)을 0.8 $\mathrm{mL}$ 가한 후 항온수조에서 $37^{\circ} \mathrm{C}$ 에서 30 분 반응시키고, 405 $\mathrm{nm}$ 에서의 흡광도를 측정하여 대조군인 acarbose(Sigma Chemical Co.)와 비교하여 계산하였다. 결과값은 3 회 반복 수행하여 도출한 평균값을 제시하였으며, 계산식은 다음와 같다.

$\alpha$-Glucosidase inhibition rate $(\%)=$

$$
\frac{1-\left(\mathrm{Abs}_{\text {sample }}-\mathrm{Abs}_{\text {blank }}\right)}{\mathrm{Abs}_{\mathrm{control}}} \times 100
$$

\section{항균활성 측정}

Choi의 방법(Kim과 Choi, 2011)에 따라 생육저해율 시험 은 탁도 측정법으로 진행하였고, 생육저지환 시험은 paper disc법으로 진행하였으며, 한국생물자원센터에서 분양받아 사용하였으며, 그람양성균은 Bacillus subtilis(KCTC 13241), Bacillus coagulans(KCTC 3625), Streptococcus mutans(KCTC 
3065)를, 그람음성균은 Escherichia coli(KCTC12020), Acinetobacter calcoaceticus(KCTC 2357), Proteus mirabilis(KCTC 2510)를 nutrient broth(BD Difco, New Jersey, USA)에 3회 계대배양하여 $10^{4}-10^{6} \mathrm{CFU} / \mathrm{mL}$ 의 활성을 가지는 것을 분석 에 사용하였다.

생육저해율 시험은 멸균된 시험관 배지에 발효 전후의 각 시료를 $1 \mathrm{~mL}$ 씩 분주하고 incubator에서 $37^{\circ} \mathrm{C}$ 에서 24 시간 배 양 후 $660 \mathrm{~nm}$ 에서 3회 반복 수행하여 도출한 투과율을 환산 하여 탁도로 제시하였다. 생육저지환에 의한 생육저해율 시 험은 멸균된 petri dish에 배지를 분주 후 배지 표면의 수분을 제거하고 활성 상태의 균액을 균일하게 도말하여 6시간 배양 후 멸균된 $6 \mathrm{~mm}$ filter paper $\operatorname{disc}(49005040$, Adventec, Tokyo, Japan)를 균이 접종된 배지 표면에 밀착시키고, 발효 전후의 각 시료를 $0.2 \mathrm{~mL}$ 를 분주하고 incubator에서 $37^{\circ} \mathrm{C}$ 에 서 48시간 배양하여 disc 주위의 clear zone의 직경을 $\mathrm{mm}$ 단 위로 3 회 반복 수행하여 도출한 결과값을 제시하였다.

\section{통계처리}

모든 실험 결과는 평균 \pm 표준편차 $(m e a n \pm S D)$ 로 표기하였 고, SAS program을 이용하여 one-way ANOVA를 시행하여 유의성 평가를 진행하였으며 p-value가 0.05 미만인 경우, 통 계적으로 유의하다고 판단하였다.

\section{결과 및 고찰}

\section{추출물의 발효특성}

G. hansenii, G. xylinus, A. xylinum과 같은 acetic acid bacteria는 탄소원인 glucose와 같은 당류를 이용하여 발효 과정 중 상층에 cellulose를 형성하며, acetic acid, glucuronic acid, malic acid, usnic acid와 같은 유기산을 형성하는 것으 로 보고되어(Ko 등, 2017), cellulose 두께, $\mathrm{pH}$ 및 산도 변화 는 발효 특성 확인의 중요한 척도가 된다.

제조한 발효음료의 cellulose 두께 변화는 Fig. $1 \mathrm{~A}$ 와 같이 증가하는 경향을 보였으며, 발효 6일 차부터 5.17-6.73 mm로 각 배합에 따른 유의적인 차이가 나타났고, 15 일 차에 7.17$8.30 \mathrm{~mm}$ 의 두께를 형성하는 것으로 나타났다. $\mathrm{pH}$ 는 Fig. 1B 와 같이 발효 0 일 차에는 5.84-5.86으로 나타났으며, 이후 유 의적으로 감소하여 3 일 차에 4.95-5.12로 나타났으며, 지속적 으로 감소하여 15 일 차에는 3.68-3.93으로 나타났다. 산도는 Fig. 1 와 같이 발효 0 일 차에는 $0.04-0.05 \%$ 로 유의적인 차 이가 나타나지 않았으나, 3 일 차부터 $1.85-2.11 \%$ 로 배합에 따른 유의적인 증가하였으며, 지속적으로 증가하여 15 일 차 에 3.41-3.77\%로 나타났다.

이는 G. hansenii TF-2로 산머루를 원료로 제조한 산형발
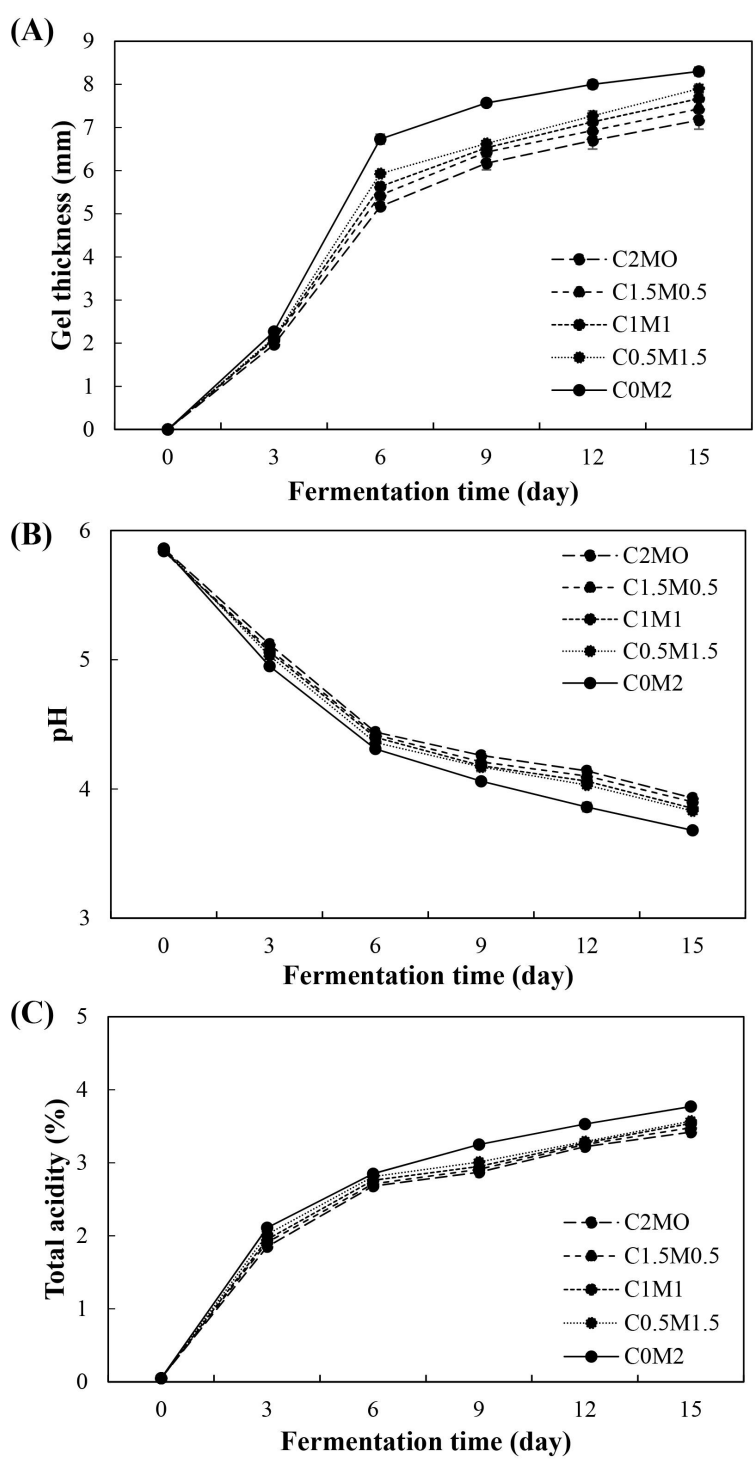

Fig. 1. Changes in the cellulose thickness (A), pH (B) and total acidity $(\mathrm{C})$ of the fermented beverages according to the fermentation period.

C2M0, corn silk $2 \%+$ mulberry leaves $0 \% ; \mathrm{C} 1.5 \mathrm{M} 0.5$, corn silk $1.5 \%$ +mulberry leaves $0.5 \%$; C1M1, corn silk $1 \%+$ mulberry leaves $1 \%$; C0.5M1.5, corn silk $0.5 \%$ +mulberry leaves $1.5 \%$; C0M2, corn silk $0 \%+$ mulberry leaves $2 \%$.

All values are expressed as mean $\pm \mathrm{SD}(\mathrm{n}=3)$.

효음료가 발효 8 일 차에 약 6-6.4 mm, 발효 15일째 7.0-7.5 $\mathrm{mm}$ 두께의 cellulose 막을 형성한다는 보고(Wei, 2020)와, 녹차, 동충하초 및 감귤 착즙 희석액을 원료로 제조한 콤부차 가 발효 15 일 차에 약 $2.0-3.9$ 의 $\mathrm{pH}, 1.5-2.9 \%$ 의 산도를 나타 낸다는 보고와 유사한 경향을 나타냈다(Moon, 2013).

G. xylinus의 활성 여부를 판단할 수 있는 cellulose 두께, $\mathrm{pH}$ 및 산도에서 선행 연구와 유사한 경향을 나타냄에 따라 옥수수수염, 뽕잎의 배합에 따른 발효음료 제조 시 원활한 발 
효가 진행되는 것으로 판단된다.

\section{총플라보노이드 및 총페놀 함량}

옥수수수염, 뽕잎의 배합에 따른 발효음료의 총플라보노 이드 함량은 Fig. 2A와 같이 발효 0일 차에는 34.60-161.87 $\mu \mathrm{g} / \mathrm{mL}$ 에서 발효 15 일 차에는 37.42-164.65 $\mu \mathrm{g} / \mathrm{mL}$ 로 나타났 으며, 총 페놀 함량은 Fig. 2B와 같이 발효 0일 차에는 137.50$615.87 \mu \mathrm{g} / \mathrm{mL}$ 에서 발효 15 일 차에는 $138.67-620.17 \mu \mathrm{g} / \mathrm{mL}$ 로 나타났으며, 뽕잎의 배합이 증가함에 따라 총플라보노이 드 및 페놀 함량이 유의적으로 증가하는 것으로 나타났다.

Kim 등(2016)은 anthoxanthin, anthocyanidin 등을 포함한 플라보노이드 화합물은 식물에 다량 함유된 2차 대사산물인 페놀성 화합물로 phenolic hydroxyl기를 가지고 있어 체내에 서 강한 항산화제로 작용하여 DNA 세포막 산화 억제, LDL 의 산화 억제로 혈관계를 보호할 뿐만 아니라, 항암, 항균 효 과도 있는 것으로 보고하였으며, Jang 등(2012)은 약용 식물
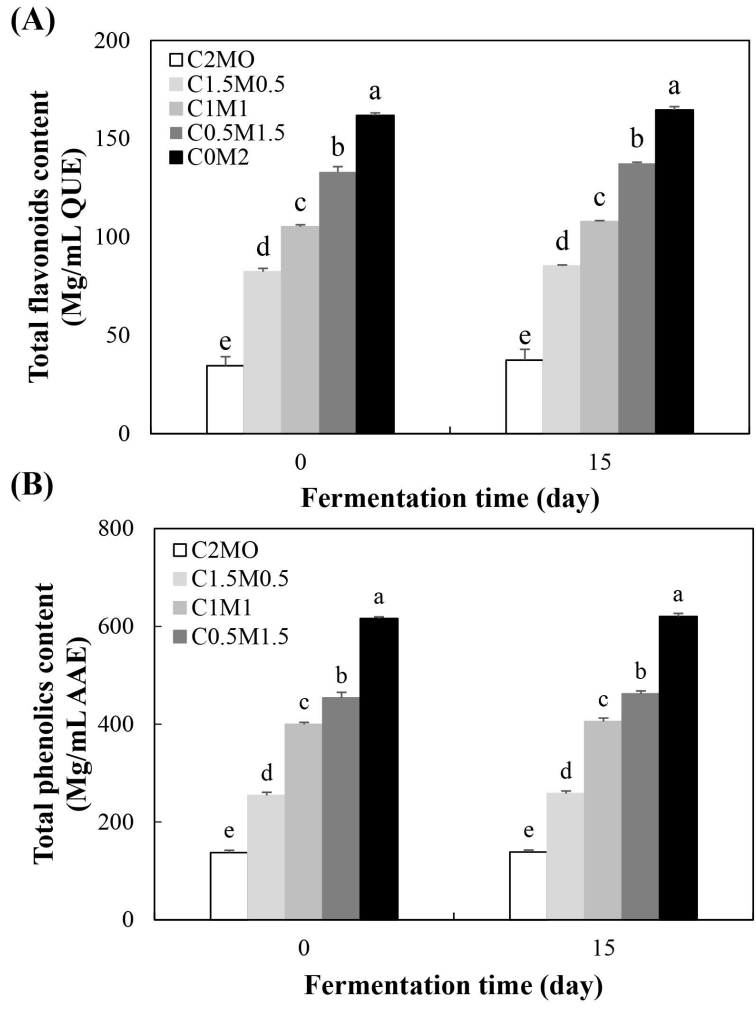

Fig. 2. Chanes in total flavonoid and total phenolics contents of the fermented beverage accoridng to the fermentation period.

C2M0, corn silk $2 \%+$ mulberry leaves $0 \%$; $1.5 \mathrm{M} 0.5$, corn silk $1.5 \%$ +mulberry leaves $0.5 \%$; C1M1, corn silk $1 \%$ +mulberry leaves $1 \%$; C0.5M1.5, corn silk $0.5 \%+$ mulberry leaves $1.5 \%$; C0M2, corn silk $0 \%+$ mulberry leaves $2 \%$.

All values are expressed as mean $\pm \mathrm{SD}(\mathrm{n}=3)$ and within a column with different superscript letters are significantly different from each other at $\mathrm{p}<0.05$.
에 대한 페놀성 화합물 함량과 플라보노이드 화합물 함량의 상관관계를 확인하였을 때, 페놀성 화합물의 함량이 높을수 록 플라보노이드 화합물의 함량도 비례하게 증가한다고 보고 하였다. 본 실험에서 발효 기간에 따른 플라보노이드 및 페놀 화합물의 함량이 유의적 차이는 나타나지 않으나, 소폭 증가 하는 것은 G.xylinus로 발효함에 따라 생성된 acetic acid, glucuronic acid 등의 유기산에 의한 것으로 판단되며, 옥수 수수염에 비해 뽕잎이 높은 플라보노이드 및 페놀 화합물 함 량이 나타난 것은 원료 자체가 함유한 함량의 차이에서 나타 난 결과로 판단된다. 이는 에탄올을 용매로 추출 시 옥수수수 염은 $53.2 \mu \mathrm{g} / \mathrm{g}$, 뽕잎은 $180.3 \mu \mathrm{g} / \mathrm{g}$ 의 플라보노이드 화합물 함량을 가진다는 Park(2017)의 선행연구와 유사한 경향을 나 타냈으며, 이를 통해 옥수수수염, 뽕잎의 배합에 따른 발효음 료 제조 시 원료의 배합에 따른 기능성분의 상승효과는 나타 나지 않으나, 뽕잎의 배합이 증가함에 따라 총플라보노이드 및 페놀 함량이 유의적으로 증가함에 따라 해당 원료를 활용 한 발효음료의 개발이 유의미하다는 것을 확인하였다.

\section{항산화 활성}

발효 전후에 따른 발효음료의 DPPH 라디칼 소거능은 Fig. $3 \mathrm{~A}$ 와 같이, 발효 0 일 차에는 $21.33-64.16 \%$ 에서 발효 15 일 차에는 23.87-69.39\%로 발효 전후에 따른 유의적인 차이가 나타나지 않았으나, 뽕잎의 첨가량이 증가함에 따라 발효 전 후 모두 유의적으로 높은 소거능을 가지는 것으로 보아 옥수 수수염에 비해 뽕잎의 항산화 활성이 우수한 것으로 나타났 다. ABTS 라디칼 소거능은 Fig. $3 \mathrm{~B}$ 와 같이, 발효 0 일 차에는 $51.94-68.61 \%$ 에서 발효 15 일 차에는 59.92-75.68\%로 DPPH 라디칼 소거능과 같이 발효 전후에 따른 유의적인 차이는 나 타나지 않았으나, 옥수수수염에 비해 뽕잎의 첨가량이 증가함 에 따라 발효 전후 모두 유의적으로 높은 소거능을 가지는 것 으로 나타났다. 환원력은 Fig. $3 \mathrm{C}$ 와 같이, 발효 0 일 차에는 $22.90-70.73 \%$ 에서 발효 15 일 차에는 $27.27-82.33 \%$ 로 발효 기 간의 경과에 따른 유의적 차이는 나타나지 않았으나, 뽕잎의 첨가량이 증가함에 따라 환원력이 증가하는 경향을 나타냈다.

$\mathrm{DPPH}$ 라디칼 소거능은 시료의 항산화 물질이 안정화 상 태의 자유 라디칼로 존재하고 있는 DPPH와 재반응하여 1,1diphenyl-2-picrylhydrazine으로 변화하는 원리로 작용하며, 비교적 간편하고 비용이 저렴하여 대표적인 항산화 활성 분 석 지표로 활용되고 있는 방법이지만, 분석에 사용되는 시료 특성상 빛, $\mathrm{pH}$, 온도 등 주변 환경에 민감하게 영향을 받는 것이 단점으로 보고되고 있다(Yoo 등, 2007). 하지만 ATBS 라디칼 소거능의 경우, DPPH 라디칼 소거능과 달리 단순한 수용성 물질의 수소공여능뿐만 아니라, 연쇄 산화 반응 억제 를 함께 측정하고, 지용성 물질 모두를 분석할 수 있기 때문 

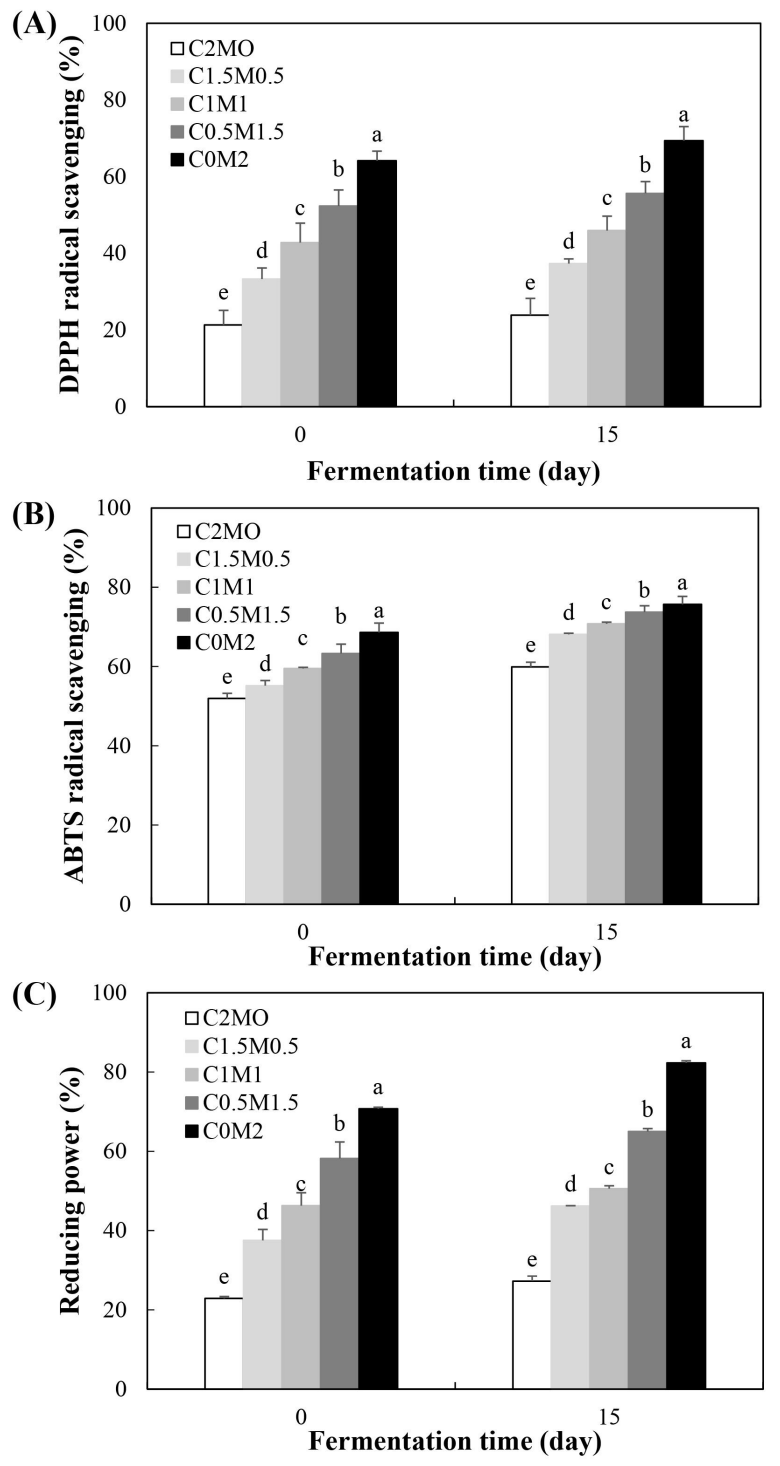

Fig. 3. Changes in DPPH radical scavenging (A), ABTS radical scavenging (B) and reducing power (C) of the fermented beverage according to the fermentation period.

C2M0, corn silk $2 \%+$ mulberry leaves $0 \%$; $1.5 \mathrm{M} 0.5$, corn silk $1.5 \%$ +mulberry leaves $0.5 \%$; C1M1, corn silk $1 \%+$ +mulberry leaves $1 \%$; C0.5M1.5, corn silk $0.5 \%+$ mulberry leaves $1.5 \%$; C0M2, corn silk $0 \%+$ mulberry leaves $2 \%$.

All values are expressed as mean $\pm \mathrm{SD}(\mathrm{n}=3)$ and within a column with different superscript letters are significantly different from each other at $\mathrm{p}<0.05$.

에 이와 같은 차이가 나타난다고 보고된 바 있는 것으로 보아 옥수수수염의 배합에 따른 소거능의 차이가 나타난 것으로 판단된다(Song 등, 2017; Kwon 등, 2020). 옥수수수염의 항 산화 활성 분석에 대한 선행 연구 결과에서도 $\mathrm{ABTS}$ 라디칼 소거능 분석 시 설정하는 $734 \mathrm{~nm}$ 가 DPPH 라디칼 소거능 분 석 시 설정하는 $517 \mathrm{~nm}$ 에 비해 옥수수수염 추출물의 가시
영역에 영향을 받지 않는 것이 확인된 바 있다. 이를 종합적으 로 판단하였을 때, 옥수수수염이 함유한 안토시아닌이 DPPH 라디칼 소거능 분석시 가시 영역의 간섭이 나타나지만, ABTS 라디칼 소거능 분석 시 정밀하게 분석되어져 소거능의 차이 가 나타난 것으로 판단된다.

항산화 활성 분석을 위해 진행한 DPPH 라디칼 소거능, $\mathrm{ABTS}$ 라디칼 소거능, 환원력에서 분석법에 따라 동일 배합 비에서 결과값의 차이가 나타나기도 하였으나, 일반적으로 뽕잎의 배합량이 증가함에 따라 유의적으로 높은 항산화 활 성이 있음을 확인하였다. 이는 원료에 따라 함유한 플라보노 이드 및 페놀 화합물의 차이가 있기 때문인 것으로 판단되며, 실제 제조에 사용한 옥수수수염과 뽕잎 $2 \%(\mathrm{w} / \mathrm{v})$ 추출물의 총플라보노이드 함량은 $34.25 \mu \mathrm{g} / \mathrm{mL}, 160.46 \mu \mathrm{g} / \mathrm{mL}$, 총 페 놀 함량은 $135.84 \mu \mathrm{g} / \mathrm{mL}, 614.58 \mu \mathrm{g} / \mathrm{mL}$ 로 항산화 활성 결과 와 동일한 경향을 나타냈다.

\section{$\alpha$-Glucosidase 저해 활성}

$\alpha$-Glucosidase 저해 활성은 1 회 기본 투약 및 섭취량을 고 려하여 양성 대조군인 acarbose는 $5 \mathrm{mg} / \mathrm{mL}$, 옥수수수염, 뽕잎 추출물의 배합에 따른 발효음료는 $10 \mathrm{mg} / \mathrm{mL}$ 의 농도로 분석하 였다. 결과는 Table 2 와 같이 대조군인 acarbose는 $85.63 \%$, 제 조한 발효음료는 $22.51-38.66 \%$ 의 저해 활성을 가지는 것으 로 나타났으며, 특히 옥수수수염에 비해 뽕잎의 첨가량이 증 가함에 따라 저해 활성이 높은 것을 확인하였다. 이는 뽕잎이 $5.00 \mathrm{mg} / 100 \mathrm{~g}, 3.50 \mathrm{mg} / 100 \mathrm{~g}$ 이상 함유하고 있는 것으로 보고된 1-deoxynojirimycin과 $\gamma$-aminobutyric acid 때문인 것 으로 판단된다(Kim, 2017; Lee, 2015). 선행연구에서 원료에

Table 2. $\alpha$-Glucosidase inhibition activity of fermented beverage using corn silk and mulberry leaf extracts

\begin{tabular}{ccc}
\hline Samples $^{1)}$ & $\begin{array}{c}\text { Concentration } \\
(\mathrm{mg} / \mathrm{mL})\end{array}$ & $\begin{array}{c}\text { Inhibition } \\
(\%)\end{array}$ \\
\hline Acarbose & 5 & $85.63 \pm 3.11^{\mathrm{a} 2)}$ \\
C2M0 & 10 & $22.51 \pm 2.02^{\mathrm{e}}$ \\
C1.5M0.5 & 10 & $29.02 \pm 1.09^{\mathrm{d}}$ \\
C1M1 & 10 & $30.31 \pm 1.41^{\mathrm{d}}$ \\
C0.5M1.5 & 10 & $34.94 \pm 0.94^{\mathrm{c}}$ \\
C0M2 & 10 & $38.66 \pm 1.39^{\mathrm{b}}$ \\
\hline
\end{tabular}

${ }^{1)} \mathrm{C} 2 \mathrm{M} 0$, corn silk $2 \%+$ mulberry leaves $0 \% ; \mathrm{C} 1.5 \mathrm{M} 0.5$, corn silk $1.5 \%$ +mulberry leaves $0.5 \%$; C1M1, corn silk $1 \%+$ mulberry leaves $1 \%$; C $0.5 \mathrm{M} 1.5$, corn silk $0.5 \%+$ mulberry leaves $1.5 \%$; $\mathrm{C} 0 \mathrm{M} 2$, corn silk $0 \%+$ mulberry leaves $2 \%$.

${ }^{2)}$ All values are expressed as mean $\pm \mathrm{SD}(\mathrm{n}=3)$ and within a column with different superscript letters are significantly different from each other at $\mathrm{p}<0.05$. 
따른 $\alpha$-glucosidase 저해 활성 분석 결과에서는 구기자 분말 을 ethyl alcohol을 용매로 $1 \mathrm{~g} / 30 \mathrm{~mL}$ 의 농도로 추출 시 $49.43 \%$ 의 저해 활성을 가지며, 레몬과 오렌지 과피 추출물은 $10 \mathrm{mg} / \mathrm{mL}$ 농도에서 35.63-35.18\%의 저해 활성이 있는 것으 로 보고되었다(Lee, 2015).

옥수수수염과 뽕잎의 배합에 따른 발효음료는 양성대조군 인 acarbose에 비해서는 저해 활성이 낮지만, 선행연구에서 분석에 사용한 원료들과 비교하였을 때 $\alpha$-glucosidase 저해
활성이 있는 것으로 확인되며 $\alpha$-glucosidase 저해 활성이 있 는 천연 원료로서 다양한 소재에 대한 응용 가능성이 있음을 확인하였다.

\section{항균활성}

옥수수수염, 뽕잎의 배합에 따른 발효음료의 발효 전후 및 농도에 따른 항균 활성 비교를 위해 탁도 측정법으로 실험한 생육 저해율의 결과는 Table 3 과 같다.

Table 3. Growth inhibition (\%) of the fermented beverages against food-related bacteria

\begin{tabular}{|c|c|c|c|c|c|c|c|c|}
\hline \multirow{2}{*}{ Gram } & \multirow{2}{*}{$\begin{array}{l}\text { Bacterial } \\
\text { strains }\end{array}$} & \multirow{2}{*}{ Day ${ }^{1)}$} & \multirow{2}{*}{$\begin{array}{c}\text { Conc. } \\
(\%)\end{array}$} & \multicolumn{5}{|c|}{ Samples $^{2)}$} \\
\hline & & & & $\mathrm{C} 2 \mathrm{M} 0$ & $\mathrm{C} 1.5 \mathrm{M} 0.5$ & C1M1 & $\mathrm{C} 1.5 \mathrm{M} 0.5$ & $\mathrm{C} 0 \mathrm{M} 2$ \\
\hline \multirow{12}{*}{+} & \multirow{4}{*}{ B. subtilis } & \multirow{2}{*}{0} & 50 & $18.18 \pm 2.28^{\mathrm{e} 3)}$ & $23.52 \pm 3.65^{\mathrm{d}}$ & $27.82 \pm 1.62^{\mathrm{c}}$ & $30.66 \pm 0.75^{b}$ & $35.42 \pm 1.86^{\mathrm{a}}$ \\
\hline & & & 100 & $29.12 \pm 2.29^{\mathrm{d}}$ & $31.40 \pm 2.45^{\mathrm{cd}}$ & $33.38 \pm 1.19^{\mathrm{c}}$ & $36.75 \pm 1.69^{\mathrm{b}}$ & $42.67 \pm 1.26^{\mathrm{a}}$ \\
\hline & & \multirow{2}{*}{15} & 50 & $41.90 \pm 0.62^{\mathrm{d}}$ & $44.92 \pm 0.31^{\mathrm{d}}$ & $49.24 \pm 1.15^{\mathrm{c}}$ & $53.26 \pm 3.58^{b}$ & $66.29 \pm 1.15^{\mathrm{a}}$ \\
\hline & & & 100 & $51.36 \pm 1.40^{\mathrm{d}}$ & $56.84 \pm 3.03^{\mathrm{c}}$ & $68.23 \pm 3.60^{\mathrm{b}}$ & $72.27 \pm 6.42^{\mathrm{b}}$ & $84.68 \pm 0.56^{\mathrm{a}}$ \\
\hline & \multirow{4}{*}{ B. coagulans } & \multirow{2}{*}{0} & 50 & $16.580 .20^{\mathrm{e}}$ & $18.69 \pm 0.70^{\mathrm{d}}$ & $24.49 \pm 0.41^{\mathrm{c}}$ & $26.00 \pm 1.18^{\mathrm{b}}$ & $34.30 \pm 0.83^{\mathrm{a}}$ \\
\hline & & & 100 & $19.97 \pm 0.18^{\mathrm{e}}$ & $21.45 \pm 0.36^{\mathrm{d}}$ & $25.83 \pm 0.39^{\mathrm{c}}$ & $29.69 \pm 0.12^{\mathrm{b}}$ & $45.67 \pm 0.58^{\mathrm{a}}$ \\
\hline & & \multirow{2}{*}{15} & 50 & $37.34 \pm 1.11^{\mathrm{d}}$ & $42.65 \pm 0.52^{\mathrm{d}}$ & $51.68 \pm 1.70^{\mathrm{c}}$ & $62.40 \pm 2.36^{\mathrm{b}}$ & $85.50 \pm 2.34^{\mathrm{a}}$ \\
\hline & & & 100 & $83.40 \pm 1.35^{\mathrm{e}}$ & $87.65 \pm 0.69^{d}$ & $89.96 \pm 0.17^{\mathrm{c}}$ & $93.72 \pm 1.61^{\mathrm{b}}$ & $96.22 \pm 0.39^{a}$ \\
\hline & \multirow{4}{*}{ S. mutans } & \multirow{2}{*}{0} & 50 & $1.88 \pm 0.44^{\mathrm{d}}$ & $2.76 \pm 0.19^{c}$ & $2.97 \pm 0.31^{\mathrm{bc}}$ & $3.12 \pm 0.37^{\mathrm{bc}}$ & $3.42 \pm 0.48^{\mathrm{a}}$ \\
\hline & & & 100 & $3.28 \pm 1.12^{\mathrm{b}}$ & $3.56 \pm 0.91^{\mathrm{b}}$ & $4.01 \pm 0.97^{\mathrm{b}}$ & $4.39 \pm 1.06^{\mathrm{b}}$ & $6.37 \pm 0.86^{\mathrm{a}}$ \\
\hline & & \multirow{2}{*}{15} & 50 & $6.48 \pm 1.31^{\mathrm{d}}$ & $7.05 \pm 0.93^{\mathrm{cd}}$ & $7.44 \pm 0.88^{\mathrm{bc}}$ & $8.21 \pm 0.52^{\mathrm{ab}}$ & $8.92 \pm 0.18^{\mathrm{a}}$ \\
\hline & & & 100 & $15.57 \pm 0.41^{\mathrm{e}}$ & $18.50 \pm 1.05^{\mathrm{d}}$ & $26.03 \pm 1.11^{\mathrm{c}}$ & $34.95 \pm 0.76^{\mathrm{b}}$ & $39.46 \pm 1.13^{\mathrm{a}}$ \\
\hline \multirow{12}{*}{. } & \multirow{4}{*}{ E. coli } & \multirow{2}{*}{0} & 50 & $18.41 \pm 0.42^{\mathrm{c}}$ & $18.61 \pm 0.91^{\mathrm{c}}$ & $19.52 \pm 1.01^{b c}$ & $20.57 \pm 1.81^{b}$ & $25.42 \pm 0.94^{\mathrm{a}}$ \\
\hline & & & 100 & $19.58 \pm 0.68^{\mathrm{e}}$ & $21.18 \pm 1.74^{\mathrm{d}}$ & $23.52 \pm 1.85^{\mathrm{c}}$ & $26.23 \pm 0.56^{\mathrm{b}}$ & $28.06 \pm 1.29^{\mathrm{a}}$ \\
\hline & & \multirow{2}{*}{15} & 50 & $73.70 \pm 0.63^{d}$ & $75.14 \pm 0.75^{\mathrm{c}}$ & $77.39 \pm 0.30^{\mathrm{b}}$ & $80.13 \pm 4.97^{\mathrm{a}}$ & $81.28 \pm 1.53^{\mathrm{a}}$ \\
\hline & & & 100 & $79.43 \pm 1.51^{\mathrm{c}}$ & $79.73 \pm 2.39^{c}$ & $80.53 \pm 1.82^{\mathrm{bc}}$ & $81.42 \pm 1.69^{\mathrm{b}}$ & $84.18 \pm 1.51^{\mathrm{a}}$ \\
\hline & \multirow{4}{*}{ A. calcoaceticus } & \multirow{2}{*}{0} & 50 & $21.84 \pm 0.78^{\mathrm{d}}$ & $24.92 \pm 0.66^{\mathrm{c}}$ & $28.24 \pm 0.71^{\mathrm{b}}$ & $29.20 \pm 0.69^{b}$ & $33.30 \pm 0.59^{\mathrm{a}}$ \\
\hline & & & 100 & $34.93 \pm 0.51^{\mathrm{b}}$ & $37.52 \pm 0.16^{\mathrm{b}}$ & $40.90 \pm 0.22^{\mathrm{ab}}$ & $46.89 \pm 0.14^{\mathrm{ab}}$ & $53.59 \pm 0.43^{\mathrm{a}}$ \\
\hline & & \multirow{2}{*}{15} & 50 & $70.49 \pm 0.58^{\mathrm{e}}$ & $76.00 \pm 1.26^{\mathrm{d}}$ & $77.80 \pm 1.53^{\mathrm{c}}$ & $86.39 \pm 1.23^{\mathrm{b}}$ & $95.01 \pm 1.39^{\mathrm{a}}$ \\
\hline & & & 100 & $83.59 \pm 1.63^{\mathrm{c}}$ & $96.15 \pm 0.45^{\mathrm{b}}$ & $96.58 \pm 0.28^{b}$ & $98.22 \pm 0.41^{\mathrm{a}}$ & $99.47 \pm 0.28^{\mathrm{a}}$ \\
\hline & \multirow{4}{*}{ P. mirabilis } & \multirow{2}{*}{0} & 50 & $14.93 \pm 1.03^{\mathrm{e}}$ & $18.52 \pm 0.27^{\mathrm{d}}$ & $24.44 \pm 0.53^{\mathrm{c}}$ & $25.55 \pm 0.26^{\mathrm{b}}$ & $28.48 \pm 0.52^{\mathrm{a}}$ \\
\hline & & & 100 & $34.97 \pm 1.16^{\mathrm{c}}$ & $36.74 \pm 2.03^{\mathrm{bc}}$ & $38.42 \pm 0.60^{\mathrm{b}}$ & $40.56 \pm 0.98^{\mathrm{a}}$ & $41.48 \pm 1.01^{\mathrm{a}}$ \\
\hline & & \multirow{2}{*}{15} & 50 & $40.75 \pm 4.12^{\mathrm{b}}$ & $48.70 \pm 1.34^{\mathrm{a}}$ & $50.011 .34^{\mathrm{a}}$ & $51.32 \pm 1.34^{\mathrm{a}}$ & $55.33 \pm 9.23^{\mathrm{a}}$ \\
\hline & & & 100 & $52.75 \pm 2.59^{\mathrm{d}}$ & $54.81 \pm 2.08^{\mathrm{cd}}$ & $57.57 \pm 2.38^{\mathrm{bc}}$ & $59.31 \pm 0.74^{\mathrm{b}}$ & $63.43 \pm 1.20^{\mathrm{a}}$ \\
\hline
\end{tabular}

${ }^{1)} 0$ and 15 days are before and after fermentation.

${ }^{2)} \mathrm{C} 2 \mathrm{M} 0$, corn silk $2 \%+$ mulberry leaves $0 \%$; C1.5M0.5, corn silk $1.5 \%+$ mulberry leaves $0.5 \%$; $\mathrm{C} 1 \mathrm{M} 1$, corn silk $1 \%+$ mulberry leaves $1 \%$; $\mathrm{C} 0.5 \mathrm{M} 1.5$, corn silk $0.5 \%+$ mulberry leaves $1.5 \%$; COM2, corn silk $0 \%$ +mulberry leaves $2 \%$.

${ }^{3)}$ All values are expressed as mean $\pm \mathrm{SD}(\mathrm{n}=3)$ and within a column with different superscript letters are significantly different from each other at $\mathrm{p}<0.05$. 
발효 전후 및 농도에 따라 유의적으로 투과율이 증가하는 경향을 나타냈으며, 옥수수수염의 배합량이 증가함에 따라 그 람음성균에 대한 항균 활성이 유의적으로 높게 나타났으며, 뽕잎의 배합량의 증가에 따라서는 모든 균주에 대해 유의적으 로 높은 항균 활성을 가지는 것을 확인하였다. 특이적으로 의 료용 도구에 쉽게 번식하는 것으로 보고된 A. calcoaceticus, 내열성이 강한 B. coagulans, 대표적 식중독균의 하나인 $E$. coli에 대해서는 원료의 배합비와 무관하게 모두 $80.00 \%$ 이상 의 유의적으로 높은 생육 저해율을 나타냈다(Konuray와 Erginkaya, 2018; Liu, 2018).

옥수수수염, 뽕잎의 배합에 따른 발효음료의 발효 전후의 항균 활성 비교 분석을 위해 식품과 관련한 6 종의 세균에 대 해 paper disc 법으로 실험한 생육저지환의 결과는 Table 4 와 같다.

발효 0 일 차와 15 일 차의 생육 저지환의 직경은 평균 $5.75 \pm 1.41 \mathrm{~mm}$ 의 유의적인 차이가 나타났으며, 옥수수수염은 그람음성균에 대해, 뽕잎은 모든 공시 균주에 대해 생육 저해 율 분석 결과와 같이 유의적으로 높은 항균 활성이 있음을 확인하였다. 뽕잎 추출물은 chlorogenic acid를 함유하여 항 균 활성이 있는 것으로 보고되었으며, 특히 S. mutans에 대해 유의적으로 높은 항균 활성이 있다는 선행 연구 결과와 동일한 결과를 나타냈으며, 옥수수수염 추출물은 luteolin 3-methyl ether 7-glucuronosyl-glucuronide-(1 $\rightarrow 2$ )-glucuron ide를 함유 하고 있어 E. coli와 같은 그람음성균에 대한 항균 활성이 우수 하다는 선행 연구 결과 $(\mathrm{Oh}, 2017)$ 와 동일한 양상을 나타냈다.

탁도 측정법과 paper disc법으로 분석한 항균 활성은 옥수 수수염과 뽕잎의 배합에 따른 항균 활성의 상승효과는 나타 나지 않았으나, 옥수수수염은 그람음성균, 뽕잎은 모든 공시 균주에 대해 항균 활성을 나타냈다. 이는 산형발효음료 제조 중 G.xylinus의 발효로 생성되는 glucuronic acid, citric acid 와 같은 유기산에 의해 항균 활성이 나타난 것으로 판단되며, 이를 통해 인체에 유해한 식중독균의 성장이 비교적 쉽게 발 생하는 비살균음료인 산형발효음료의 안전성을 확보할 수 있 음을 확인하였다.

\section{요 약}

본 연구에서는 maysin, $\gamma$-aminobutyric acid 등의 생리활성 물질을 함유하여 항산화, 항당뇨 활성이 있는 것으로 보고된 옥수수수염과 뽕잎을 배합하여 제조한 발효음료에 대한 발효 적성, 기능성분 및 항산화, 항당뇨, 항균 활성을 비교 분석함 으로써 원료 배합에 따른 기능성분 등의 상승효과 및 영양적, 기능성으로 최적인 배합비를 탐색하고자 진행되었다. 그 결과 로 발효 15일 차에 7.17-8.30 mm 두께의 cellulose, 3.68-3.93

Table 4. Zone of inhibition (mm) of the fermented beverages against food-related bacteria

\begin{tabular}{|c|c|c|c|c|c|c|c|}
\hline \multirow{2}{*}{ Gram } & \multirow{2}{*}{ Bacterial strains } & \multirow{2}{*}{ Day $^{1)}$} & \multicolumn{5}{|c|}{ Samples $^{2)}$} \\
\hline & & & $\mathrm{C} 2 \mathrm{M} 0$ & C1.5M0.5 & C1M1 & C1.5M0.5 & $\mathrm{C} 0 \mathrm{M} 2$ \\
\hline \multirow{6}{*}{+} & \multirow{2}{*}{ B. subtilis } & 0 & $6.26 \pm 0.05^{\mathrm{d} 3)}$ & $7.05 \pm 0.11^{\mathrm{c}}$ & $7.32 \pm 0.03^{b}$ & $7.46 \pm 0.08^{\mathrm{ab}}$ & $7.60 \pm 0.09^{\mathrm{a}}$ \\
\hline & & 15 & $10.97 \pm 0.14^{\mathrm{d}}$ & $10.15 \pm 0.12^{\mathrm{c}}$ & $12.96 \pm 0.07^{\mathrm{b}}$ & $13.32 \pm 0.24^{\mathrm{a}}$ & $13.45 \pm 0.19^{\mathrm{a}}$ \\
\hline & \multirow{2}{*}{ B. coagulans } & 0 & $6.77 \pm 0.07^{\mathrm{d}}$ & $6.96 \pm 0.03^{c}$ & $7.04 \pm 0.02^{\mathrm{c}}$ & $7.17 \pm 0.01^{b}$ & $7.35 \pm 0.05^{\mathrm{a}}$ \\
\hline & & 15 & $12.86 \pm 0.16^{\mathrm{e}}$ & $13.47 \pm 0.08^{\mathrm{d}}$ & $13.97 \pm 0.07^{\mathrm{c}}$ & $14.38 \pm 0.04^{\mathrm{b}}$ & $14.67 \pm 0.05^{\mathrm{a}}$ \\
\hline & \multirow{2}{*}{ S. mutans } & 0 & $6.29 \pm 0.02^{\mathrm{e}}$ & $6.37 \pm 0.02^{\mathrm{d}}$ & $6.42 \pm 0.02^{\mathrm{c}}$ & $6.54 \pm 0.06^{\mathrm{b}}$ & $6.71 \pm 0.04^{\mathrm{a}}$ \\
\hline & & 15 & $9.85 \pm 0.09^{\mathrm{d}}$ & $9.96 \pm 0.10^{\mathrm{d}}$ & $10.18 \pm 0.13^{\mathrm{c}}$ & $10.49 \pm 0.04^{\mathrm{b}}$ & $10.75 \pm 0.04^{\mathrm{a}}$ \\
\hline \multirow{6}{*}{ - } & \multirow{2}{*}{ E. coli } & 0 & $6.34 \pm 0.02^{\mathrm{e}}$ & $6.40 \pm 0.03^{\mathrm{d}}$ & $6.46 \pm 0.04^{c}$ & $6.51 \pm 0.04^{\mathrm{b}}$ & $6.62 \pm 0.04^{\mathrm{a}}$ \\
\hline & & 15 & $13.33 \pm 0.02^{\mathrm{e}}$ & $13.72 \pm 0.04^{\mathrm{d}}$ & $14.01 \pm 0.03^{\mathrm{c}}$ & $14.23 \pm 0.01^{\mathrm{b}}$ & $14.48 \pm 0.08^{\mathrm{a}}$ \\
\hline & \multirow{2}{*}{ A. calcoaceticus } & 0 & $7.25 \pm 0.04^{\mathrm{e}}$ & $7.34 \pm 0.03^{\mathrm{d}}$ & $7.42 \pm 0.01^{\mathrm{c}}$ & $7.51 \pm 0.03^{\mathrm{b}}$ & $7.63 \pm 0.02^{\mathrm{a}}$ \\
\hline & & 15 & $13.52 \pm 0.09^{\mathrm{e}}$ & $13.74 \pm 0.16^{\mathrm{d}}$ & $14.00 \pm 0.82^{\mathrm{c}}$ & $14.30 \pm 0.06^{\mathrm{b}}$ & $14.48 \pm 0.06^{\mathrm{a}}$ \\
\hline & \multirow{2}{*}{ P. mirabilis } & 0 & $7.34 \pm 0.02^{\mathrm{e}}$ & $7.52 \pm 0.03^{\mathrm{d}}$ & $7.67 \pm 0.03^{\mathrm{c}}$ & $7.76 \pm 0.03^{\mathrm{b}}$ & $7.95 \pm 0.03^{\mathrm{a}}$ \\
\hline & & 15 & $12.19 \pm 0.02^{\mathrm{e}}$ & $12.35 \pm 0.01^{\mathrm{d}}$ & $12.46 \pm 0.04^{\mathrm{c}}$ & $12.56 \pm 0.03^{\mathrm{b}}$ & $12.85 \pm 0.05^{\mathrm{a}}$ \\
\hline
\end{tabular}

${ }^{1)} 0$ and 15 days are before and after fermentation.

${ }^{2)} \mathrm{C} 2 \mathrm{M} 0$, corn silk $2 \%+$ mulberry leaves $0 \%$; C1.5M0.5, corn silk $1.5 \%+$ mulberry leaves $0.5 \%$; $\mathrm{C} 1 \mathrm{M} 1$, corn silk $1 \%+$ mulberry leaves $1 \%$; $\mathrm{C} 0.5 \mathrm{M} 1.5$, corn silk $0.5 \%+$ mulberry leaves $1.5 \%$; C $0 \mathrm{M} 2$, corn silk $0 \%+$ mulberry leaves $2 \%$.

${ }^{3)}$ All values are expressed as mean $\pm \mathrm{SD}(\mathrm{n}=3)$ and within a column with different superscript letters are significantly different from each other at $\mathrm{p}<0.05$. 
의 $\mathrm{pH}, 3.41-3.77 \%$ 의 산도로 모든 배합비에서 G. xylinus 균 주의 생육이 있는 것으로 나타났다. 총플라보노이드 및 페놀 함 량은 발효 전후에 따른 차이는 없었으나 37.42-164.65 $\mu \mathrm{g} / \mathrm{mL}$, 138.67-620.17 $\mu \mathrm{g} / \mathrm{mL}$ 를 함유하고 있어, DPPH 및 ABTS 라 디칼 소거능과 환원력 분석에서도 항산화 활성이 있음을 확 인하였다. 항당뇨 활성은 22.51-33.66\%로 당뇨병 치료제로 사용되고 있는 acarbose에 비해 낮은 활성이나 천연 소재로 서의 가능성이 있음을 확인하였다. 항균 활성 역시 모든 배합 비에 대해 생육저해율 및 clear zone을 형성하여 비살균음료 인 발효음료의 안전성이 확보될 수 있음을 확인하였다. 옥수 수수염과 뽕잎의 배합에 따른 발효음료의 기능성분의 상승효 과는 나타나지 않았으나, 원료 추출물에 대해 G. xylinus의 발효적성이 있음을 확인하였다.

\section{Conflict of interests}

The authors declare no potential conflict of interest.

\section{ORCID}

Se-Woong Oh https://orcid.org/0000-0002-0230-5583

Jae-Hoon Hong https://orcid.org/0000-0001-7327-5097

\section{References}

Bauer-Petrovska B, Petrushevska-Tozi L. Mineral and water soluble vitamin content in the Kombucha drink. Int $\mathrm{J}$ Food Sci Technol, 35, 201-205 (2000)

Blois MS. Antioxidant determinations by the use of a stable free radical. Nature, 181, 1199-1200 (1958)

Campisi A, Acquaviva R, Raciti G, Duro A, Rizzo M, Santagati NA. Antioxidant activities of Solanum nigrum L. leaf extracts determined in in vitro cellular models. Foods, 8, 63 (2019)

Jang MR, Hong EY, Cheong JH, Kim GH. Antioxidative components and activity of domestic Cirsium japonicum extract. J Korean Soc Food Sci Nutr, 41, 739-744 (2012)

Ji YJ, Lee EY, Lee JY, Seo KH, Kim DH, Park CG, Kim HD. Antioxidant and anti-diabetic effects of Ixeris strigosa extract. J Nutr Health, 53, 244-254 (2017)

Jo JS, In MJ, Kim DC. Effect of the roasting intensity and extraction time of coffee bean on the antioxidant activity of coffee extract. Food Eng Prog, 20, 165-169 (2016)

Kang HK, Bae IK. Antimicrobial activities of corn silk extract of Klebsiella pneumoniae. J Life Sci, 25, 13991407 (2015)

Kim HY, Seo WD, Seo KH, Lee MJ, Choi SW, Lee KS, Kim SL, Kang HJ. Antioxidative and protective effects of corn silk (Zea mays L.) extract on human HaCaT keratinocyte. Korean J Crop Sci, 61, 184-190 (2016)

Kim ML, Choi MA. Development of fermented acidic beverage using wild grape juice. Korean J Food Preserv, 18, 46-52 (2011)

Kim YJ, Kim MJ, Kim HB, Lim JD, Kim AJ. Processing of functional porridge with optimal mixture ratio of mulberry leaf powder and mulberry fruit powder. $\mathrm{J}$ Korean Soc Food Sci Nutr, 46, 1081-1090 (2017)

Ko HM, Shin SS, Park SS. Biological activities of kombucha by stater culture fermentation with Gluconacetobacter spp. J Korea Soc Food Sci Nutr, 46, 896-902 (2017)

Konuray G, Erginkaya Z. Potential use of Bacillus coagulans in the food industry. Foods, 7, 92 (2018)

Kwon HY, Choi SI, Han X, Men X, Jang GW, Choi YE, Kang JC, Choi JH, Lee OH. Antioxidant components and antioxidant activities of mixtures with Sasa quelpaertensis Nakai and Ficus erecta var. sieboldii. Korean J Food Sci Technol, 52, 369-376 (2020)

Lee JA. Quality characteristics of rice cereal bars containing different levels of mulberry leaf (Morus alba Linne) powder. Culi Sci Hos Res, 25, 119-126 (2019)

Lee KA. Antioxidative and anti-diabetes activity, and free amino acid and mineral contents of beverage with Gugija (Lycii fructus) extracts. Korean J Food Cook Sci, 31, 207-213 (2015)

Liu H, Geagea H, Roussean GM, Labrie SJ, Tremblay DM, Liu X, Moineau S. Characteriazation of the Escherichia coli virulent myophage ST32. viruses, 10, 616 (2018)

Moon JY. Study on anti-obesity effects of fermented beverages. Ph D Thesis, Jeonbuk National University, Korea, p 35-39 (2013)

Moreno MIN, Isla MI, Sampietro AR, Vattuone MA. Omparison of the free radical-scavenging activity of propolis from several regions of Argentina. J Ethnopharmacol, 71, 109-114 (2000)

Oh EB. Antimicrobial activity and deodorization effect of the extracts from mulberry leave. MS Thesis, Woosuk University, Korea, p 23-35 (2017)

Oyaizu M. Studies on products of browning reaction: 
Antioxidative activities of products of browning reaction prepared from glucosamine. Jpn J Nutr, 44, 307-315 (1986)

Park ID. Quality characteristics of cookies containing mulberry leaf (Morus alba Linne) powder. J Korean Soc Food Cult, 32, 558-565 (2017)

Re R, Pellegrini N, Proteggente A, Pannala A, Yang M, Rice-Evans C. Antioxidant activity applying an improved ABTS radical cation decolorization assay. Free Radic Biol Med, 26, 1231-1237 (1999)

Rossi JA, Singleton VL. Colorimetry of total phenolics with phosphomolybdic-phosphotungstic acid reagents. Am J Enol Vitic, 16, 144-158 (1965)

Song WY, Chun SS, Kang SK, Choi JH. Anti-oxidative activities of water and ethanol extracts from Duchesnea chrysantha. J Agric Life Sci, 51, 175-185 (2017)

Sreeramulu G, Yang Z, Knol W. Kombucha fermentation and its antimicrobial activity. J Agric Food Chem, 48, 2589-2594 (2000)

Tran KQ, Satomi T, Takahashi H. Effect of waste cornsilk fiber reinforcement on mechanical properties of soft soils. Transp Geotech, 16, 76-84 (2018)

Uzogara SG, Agu LN, Uzogara EO. A review of traditional fermented foods, condiments and beverages in Nigeria: Their benefits and possible problems. Ecol Food Nutr, 24, 267-288 (1990)

Wei X. Change of carotenoids and comparison of antioxidant activity by fermentation of Citrus kombucha. MS Thesis, Jeju National University, Korea, p 24-31 (2020)

Yoo KM, Kim DO, Lee CY. Evaluation of different methods of antioxidant measurement. Food Sci Biotechnol, 16, 177-182 (2007) 